\title{
Utilization of Sugars by Chlorella under Various Conditions
}

\author{
BY M. RODRÍGUEZ-LÓPEZ \\ Institute 'G. Marañón' Velázquez 138, Madrid-6, Spain
}

SUMMARY

The consumption and utilization of a series of carbohydrates by a strain of Chlorella pyrenoidosa under different conditions of culture was examined. Only glucose, fructose and mannose were avidly consumed; galactose was consumed in small quantities. Light was highly stimulatory for the consumption of sugars. The carbohydrates assimilated were polymerized to starch; this induced gigantism in the organisms, a considerable increase in the dry weight, and inhibition of division.

\section{INTRODUCTION}

The various conclusions that have been arrived at about the nutrition and assimilation powers not only of related species of the genus Chlorella, but also within a given species, made us ponder on the great capacity of this organism to alter or change itself biochemically, thus making its taxonomic characteristics more complex. These considerations prompted us to make a study of the behaviour of our strain of $\boldsymbol{C}$. pyrenoidosa when assimilating a series of sugars under different cultural conditions. Previously (Rodríguez-López, 1963) we showed that sugars induced gigantism in chlorella; but we felt that it would be interesting to know the behaviour of the alga towards the sugars studied; by growing cultures of it under various conditions, we investigated what sugars it could use, what quantities of these it consumed and how this consumption affected the yield, division and growth of the organism.

\section{METHODS}

An inoculum equivalent to $17 \mathrm{mg}$. dry wt. Chlorella pyrenoidosa was placed aseptically in $250 \mathrm{ml}$. Erlenmeyer flasks containing $100 \mathrm{ml}$. of basal culture medium A (Rodríguez-López, 1964). Each flask contained a $16 \mathrm{~mm}$ concentration of the sugar to be studied: glucose, fructose, mannose, galactose, xylose, arabinose rhamnose, sorbose, lactose, sucrose, maltose (Sigma Chem. Co.).

The cultures were grown in daylight and aerated with an $81 . / \mathrm{hr}$ mixture of air containing $5 \%(\mathrm{v} / \mathrm{v}) \mathrm{CO}_{2}$; other cultures were grown in daylight without aeration and still others in darkness without aeration. The temperature was maintained at $24^{\circ}$ and all flasks were periodically shaken. The experiments lasted for 4 days and controls without sugar were run. Each experiment was repeated 10 times.

Consumption of carbohydrates was determined, by difference, by the SomogyiNelson colorimetric method (1944, 1952) (the sucrose being previously hydrolysed).

Growth of the cultures was measured by counting the number of organism with a Burker-ruled haemocytometer slide and the growth index $(G I)$ determined:

$$
G I=\frac{\text { No. organisms } / \mathrm{mm}^{3} \text { at end of experiment }}{\text { No. organisms } / \mathrm{mm}^{3} \text { at beginning of experiment }} .
$$


The size of organisms was also measured by using a previously calibrated micrometer eye-piece.

The dry weights of organism were obtained by desiccation in an oven at $105^{\circ}$ to constant weight. The results of consumption of carbohydrates and increase in dry wt. are recorded with reference to $100 \mathrm{mg}$. dry wt. alga.

\section{RESULTS}

Table 1 shows the consumption of the various carbohydrates under the various culture conditions. Of the sugars studied, only glucose, fructose and mannose were consumed in significant quantities when cultures were grown in daylight without aeration. The lowest consumption was by cultures kept in darkness. Galactose and xylose were also consumed, but in smaller quantities, especially the latter. None of the other sugars was consumed. The increase in the dry wt. of alga was proportional to the consumption of carbohydrates (Table 2). Nevertheless, the growth index fresents very peculiar features, in accordance with the conditions under

Table 1. Carbohydrate (mg) consumed in $96 \mathrm{hr}$ by equiv. $100 \mathrm{mg}$. dry wt. of chlorella cultivated under various conditions, in a mineral medium with the addition of $16 \mathrm{mM}$ concentration of a sugar

\begin{tabular}{|c|c|c|c|}
\hline Sugar added & $\begin{array}{l}\text { In daylight, } \\
\text { aerated, } \\
\text { and } 24^{\circ}\end{array}$ & $\begin{array}{l}\text { In daylight, } \\
\text { no aeration, } \\
\text { and } 24^{\circ}\end{array}$ & $\begin{array}{l}\text { In darkness, } \\
\text { no aeration, } \\
\text { and } 24^{\circ}\end{array}$ \\
\hline Glucose & $528 \pm 26$ & $1228 \pm 86$ & $426 \pm 22$ \\
\hline Fructose & $441 \pm 11$ & $1162 \pm 88$ & $448 \pm 35$ \\
\hline Mannose & $480 \pm 33$ & $1114 \pm 40$ & $346 \pm 24$ \\
\hline Galactose & $102 \pm 6$ & $162 \pm 31$ & $152 \pm 22$ \\
\hline Xylose & $47 \pm 26$ & $40 \pm 22$ & o \\
\hline Ribose & o & o & $\mathbf{0}$ \\
\hline Arabinose & $\mathbf{0}$ & $\mathbf{0}$ & $\mathbf{0}$ \\
\hline Rhamnose & $\mathbf{0}$ & $\mathbf{0}$ & 0 \\
\hline Sorbose & $\mathbf{0}$ & $\mathbf{0}$ & 0 \\
\hline Lactose & $\mathbf{0}$ & $\mathbf{0}$ & $\mathbf{0}$ \\
\hline Sucrose & $\mathbf{0}$ & $\mathbf{0}$ & $\mathbf{0}$ \\
\hline Maltose & $\mathbf{0}$ & $\mathbf{0}$ & $\mathbf{0}$ \\
\hline
\end{tabular}

Table 2. Increase in weight (mg. dry wt.) of equiv. $100 \mathrm{mg}$. dry wt. of chlorella cultivated under various conditions, in a mineral medium with the addition of a $16 \mathrm{mM}$ concentration of a sugar

\begin{tabular}{|c|c|c|c|}
\hline Sugar added & $\begin{array}{l}\text { In daylight, } \\
\text { aerated, } \\
\text { and } 24^{\circ}\end{array}$ & $\begin{array}{l}\text { In daylight, } \\
\text { no aeration, } \\
\text { and } \mathbf{2 4}^{\circ}\end{array}$ & $\begin{array}{l}\text { In darkness, } \\
\text { no aeration, } \\
\text { and } \mathbf{2 4}^{\circ}\end{array}$ \\
\hline Glucose & $454 \pm 26$ & $707 \pm 57$ & $235 \pm 50$ \\
\hline Fructose & $444 \pm 23$ & $617 \pm 43$ & $231 \pm 48$ \\
\hline Mannose & $450 \pm 45$ & $617 \pm 58$ & $246 \pm 30$ \\
\hline Galactose & $307 \pm 19$ & $86 \pm 10$ & $51 \pm 3$ \\
\hline Xylose & $215 \pm 4$ & 0 & 0 \\
\hline Ribose & $222 \pm 6$ & $\mathbf{0}$ & 0 \\
\hline Arabinose & $211 \pm 5$ & 0 & 0 \\
\hline Rhamnose & $212 \pm 3$ & 0 & 0 \\
\hline Sorbose & $216 \pm 3$ & 0 & 0 \\
\hline Lactose & $255 \pm 23$ & 0 & 0 \\
\hline Sucrose & $212 \pm 4$ & o & 0 \\
\hline Maltose & $238+17$ & 0 & 0 \\
\hline Control & $260 \pm 27$ & $47 \pm 14$ & 0 \\
\hline
\end{tabular}


which the culture was kept (Table 3). Those cultures which contained assimilable sugar and were grown in daylight without aeration showed inhibition of growth to a marked degree when they contained either glucose, fructose or mannose. These experiments showed that only assimilated sugars produced giant forms (Table 3). Controls without sugar did not grow if placed in the dark.

Table 3. Groroth index over $90 \mathrm{hr}$ of chlorella cultivated in a mineral medium with or without a sugar and under differing environmental conditions

\begin{tabular}{|c|c|c|c|c|}
\hline Sugar added & $\begin{array}{l}\text { In daylight, } \\
\text { aerated } \\
\text { and } 24^{\circ}\end{array}$ & $\begin{array}{c}\text { In daylight, } \\
\text { no aeration, } \\
\text { and } 24^{\circ}\end{array}$ & $\begin{array}{c}\text { In darkness, } \\
\text { no aeration, } \\
\text { and } \mathbf{2 4}^{\circ}\end{array}$ & Giant forms \\
\hline Glucose & $\mathbf{2 \cdot 3 5}$ & 1.95 & 1.05 & Yes† \\
\hline Fructose & $\mathbf{2 \cdot 3 2}$ & $1 \cdot 97$ & $1 \cdot 07$ & Yes \\
\hline Mannose & $\mathbf{2 \cdot 3 9}$ & 1.92 & 1.06 & Yes \\
\hline Galactose & $\mathbf{3} \cdot 27$ & $2 \cdot 09$ & 1.07 & No \\
\hline Xylose & 4.78 & $2 \cdot 14$ & 0.98 & No \\
\hline Ribose & 4.98 & $2 \cdot 17$ & 1.02 & No \\
\hline Arabinose & 4.89 & $2 \cdot 14$ & $1 \cdot 09$ & No \\
\hline Rhamnose & $5 \cdot 04$ & $\mathbf{2 \cdot 2 0}$ & $1 \cdot 00$ & No \\
\hline Sorbose & 5.08 & $\mathbf{2} \cdot 20$ & 0.97 & No \\
\hline Lactose & $5 \cdot 10$ & $2 \cdot 18$ & 1.02 & No \\
\hline Sucrose & $4 \cdot 98$ & $2 \cdot 10$ & $1 \cdot 03$ & No \\
\hline Maltose & $4 \cdot 90$ & $2 \cdot 13$ & 1.00 & No \\
\hline Control* & $5 \cdot 44$ & $2 \cdot 21$ & 0.98 & No \\
\hline
\end{tabular}

\section{DISCUSSION}

Of the various carbohydrates tested only glucose, fructose and mannose were consumed in relatively large quantities; these results differ from those of Samejima \& Myers (1958). This supported our suspicion of the existence of biochemical modifications within the same species, that is to say that, as in other microorganisms, including unicellular green algae, it reveals changes at the biochemical level induced by the environment and the cultural conditions.

Sucrose, which according to Milner (1948) is a component of chlorella, was not assimilable. This suggests the existence of barriers against penetration in the cell wall or cytoplasmic membrane.

The low consumption of xylose might have been due to impurities in the samples of this sugar. In the case of galactose, which was only used during the first $60 \mathrm{hr}$, perhaps a blocking mechanism is brought into play with the result that passage of this sugar is impeded.

Table 2 shows the high consumption of sugars in cultures exposed to light and not aerated as compared with that of those kept in darkness, so that light determined a difference in consumption. Griffiths (1961) referring to the light/cell-division relationship, suspected a 'participation of some photoreaction other than photosynthesis in the control of active cell division'. In our case also a factor dependent on light and distinct from photosynthesis, which acted as a stimulant of consumption of assimilable sugars, was shown.

The quantities of sugars consumed in the cultures kept in light and aerated 
would in some way compensate for the autotrophic deficiences of the cultures chiefly during the hours of darkness at night, when also $\mathrm{CO}_{2}$ was denied to them, for it is well known that chlorella is capable of using both forms of nutrition, autotrophy and heterotrophy, simultaneously.

The increase in dry wt. in the cultures is due in our case to the reserve substances accumulated, and are in direct proportion to the quantity of sugar consumed (Tables 1 and 2), which they later polymerize, transforming it into starch, as we demonstrated previously (Rodríguez-López, 1965); for while the normal forms of chlorella contain $23 \%$ of total carbohydrates, the giant forms contain $84 \%$. So that if the alga takes from the medium glucose, fructose or mannose in quantities determined by the conditions of the culture, these sugars are polymerized by it into starch, which accumulates in the cell, causing a great increase in volume and dry wt. and producing giant forms, of measurements given by us (1963). The small quantity of galactose consumed increased the cell volume to only a very insignificant extent (Table 2).

The inhibition of cell division in all cultures exposed to light, whether aerated or not, in the presence of assimilable carbohydrates is explained (Table 3) by the desequilibrium of the consumption of these in relation to nitrogen. The lower the $\mathrm{N} / \mathrm{C}$ consumption ratio, the greater the decrease in the synthesis of nucleic acids and protein; and as a result, cell division will be negatively affected.

Giant forms produced in darkness or in light are discoloured in part in comparison with normal ones. We have shown (1965) that this phenomenon, mentioned by Ikuko Shihira-Ishikawa \& EijiHase (1964), is due to the high concentration of starch in the organism, which completely disorganizes the chloroplast and distributes the pigment in a greater cellular volume.

Where inhibition of cell division by assimilable sugars is really manifest is in cultures exposed to light and aerated. The growth in cell population remains at less than half the normal level. Under these conditions of autotrophic growth little gigantism is to be seen, despite the fact that the alga has optionally at its disposal an assimilable sugar as a source of organic carbon.

Thus, in this work with our strain of Chlorella pyrenoidosa we arrive at results similar to those obtained by Griffiths (1963) in $C$. vulgaris under the influence of glucose, that is to say, that under the conditions pointed out in our work, chlorella avidly consumes glucose, fructose and mannose, light being a very stimulating factor in the consumption of sugar. Inhibition of cell division, a notable increase in the dry wt. and significant gigantism are the results of this consumption; while if the cultures are maintained in normal autotrophic conditions, the metabolizing sugars alone will be used to make good the deficiencies, producing an increase in the dry wt., very little gigantism and markedly inhibited cell division. 


\section{REFERENCES}

GrIFFTrus, D. J. (1961). Light-induced cell division in Chlorella vulgaris, Beijerinck (Emerson strain). Ann. Bot., N.S. 25, 85.

Griffiths, D. J. (1963). The effect of glucose on cell division in Chlorella vulgaris, Beijerinck (Emerson strain). Ann. Bot., N.S., 27, 493.

Ixuko Shinira-Ishikawa \& EiJi Hase. (1964). Nutritional control of cell pigmentation in Chlorella protothecoides with special reference to the degeneration of chloroplast induced by glucose. Plant Cell Physiol. 5, 227.

Mruner, H. W. (1948). The fatty acids of Chlorella. J. biol. Chem. 176, 813.

Nezson, N. (1944). A photometric adaptation of the Somogyi method for the determination of glucose. J. biol. Chem. 153, 375.

RodnfGuez-López, M. (1963). Gigantism-inducing factors in Chlorella pyrenoidosa. Nature, Lond. 199, 506.

RODRíguEz-LOPEz, M. (1964). Influence of the inoculum and the medium on the growth of Chlorella pyrenoidosa. Nature, Lond. 203, 666.

RoDrf́uez-Lopez, M. (1965). Morphological and structural changes produced in Chlorella pyrenoidosa by assimilable sugars. Arch. Mikrobiol. 53, 319.

SamejIma, H. \& MYers, J. (1958). On the heterotrophic growth of Chlorella pyrenoidosa. J. gen. Microbiol. 18, 107.

SomoGY, M. (1952). Notes on sugar determination. J. biol. Chem. 195, 19. 